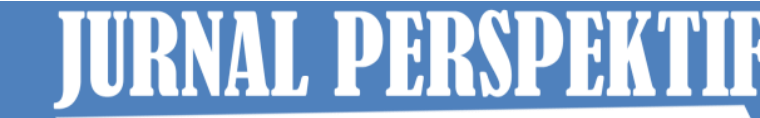 Junnal Kä|ian Sosidoci dan Pendidikkn}

Jurnal Perspektif: Jurnal Kajian Sosiologi dan Pendidikan Vol. 3 No. 2 Tahun 2020

http://perspektif.ppj.unp.ac.id

Email: perspektif@ppj.unp.ac.id

ISSN: 2622-1748 (Online), 2684-902X (Print)

DOI: http://dx.doi.org/10.24036/perspektif.v3i2.263

\title{
Resolusi Konflik Peternak Itik dengan Pemilik Sawah dan Masyarakat Kecamatan Bayang Kabupaten Pesisir Selatan
}

\author{
Kartika Afrinalsari ${ }^{1}$, Nora Susilawati ${ }^{2}$ \\ 1,2Universitas Negeri Padang \\ Email: kartikaafrinals@gmail.com, susilawatinora@gmail.com
}

\begin{abstract}
Abstrak
Penelitian ini di latarbelakangi oleh fenomena konflik antara peternak itik dengan pemilik sawah dan masyarakat Kecamatan Bayang Kabupaten Pesisir Selatan. Tujuan dalam penelitian adalah untuk menjelaskan proses resolusi konflik peternak itik dengan pemilik sawah dan masyarakat di Kecamatan Bayang Kabupaten Pesisir Selatan. Penelitian ini di analisis menggunakan teori Konflik Sosial yang di kemukakan oleh Lewis A. Coser. Penelitian ini dilakukan dengan pendekatan kualitatif, teknik pemilihan informan purposive sampling dengan jumlah informan 14 orang. Pengumpulan data yang digunakan dalam penelitian ini observasi, wawancara, dan dokumentasi, teknik triangulasi data. Teknik analisis data menggunakan konsep Miles dan Huberman. Hasil penelitian menunjukkan: proses resolusi konflik antara peternak itik dengan pemilik sawah dan masyarakat di Kecamatan Bayang Kabupaten Pesisir Selatan. Proses resolusi konflik antara peternak itik dengan pemilik sawah dan masyarakat ada tiga tahapan yaitu negosiasi antara peternak itik dengan pemilik sawah dan masyarakat, mediasi dengan Datuak, dan albitrasi dengan Wali Nagari.
\end{abstract}

Kata Kunci: Masyarakat, Pemilik Sawah, Peternak itik, Resolusi Konflik

This research is motivated by the phenomenon of conflict between duck breeders with rice field owners and the community of Kecamatan Bayang, Kabupaten Pesisir Selatan. The purpose of this research is to explain the conflict resolution process of duck breeders with rice field owners and communities in Kecamatan Bayang, Kabupaten Pesisir Selatan. This research was analyzed using Social Conflict Theory put forward by Lewis A. Coser. This research was conducted with a qualitative approach, the technique of selecting purposive sampling with 14 informants. Data collection used in this study were observation, interviews, and documentation, data triangulation techniques. Data analysis techniques using the concept of Miles and Huberman. The results showed: the process of conflict resolution between duck breeders with rice field owners and the community in Kecamatan Bayang, Kabupaten Pesisir Selatan. The conflict resolution process between duck farmers and paddy owners and the community consists of three stages, namely negotiations between duck farmers and paddy owners and the community, mediation with Datuak, and albitration with Wali Nagari.

Keywords: Community, Duck Farmers, Conflict Resolution, Rice Field Owner

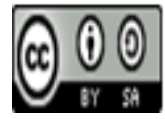

\begin{tabular}{|l|l|r} 
Received: May 19, 2020 & Revised: May 28, 2020 & Available Online: May 29, 2020 \\
\hline
\end{tabular}




\section{Pendahuluan}

Salah satu usaha peternakan unggas yang cukup berkembang di Indonesia adalah usaha ternak itik Anas domesticus (Insani, Budji, Djide, \& Hassan, 2013). Ternak itik adalah salah satu usaha budidaya jenis unggas air yang dapat mengimbangi laju pertumbuhan kebutuhan protein hewani, karena itik memiliki keunggulan di antara unggas lokal lainnya (Helmi, 2013). Ternak itik merupakan salah satu unggas yang dipelihara oleh petani peternak yang ada di Indonesia yang berperan sebagai sumber pendapatan, membuka kesempatan kerja dan sumber protein hewani baik dari daging maupun telur (Rahman, Sirajuddin, \& Asnawi, 2019). Peternak itik secara tradisional merupakan peternak yang menggiring ternaknya di sawah, sehingga menyebabkan itik tidak terawat karena itik sulit mendapatkan pakan dan mengganggu petani yang sedang bertani menyebabkan produksi telur itik menurun (Wardhani, 2015).

Umumnya di Propinsi Sumatera Barat itik masih dipelihara secara tradisional dengan penggembalaan secara berpindah-pindah. Dengan semakin sempitnya areal penggembalaan dan banyaknya resiko kematian ternak akibat keracunan pestisida maka pemeliharaan sistem gembala ini makin terancam (Lutfi, Hendriani, Suyono, Malvin, \& Mukhlis, 2018).

Sistem pemeliharaan itik akan menentukan kualitas dan kuantitas produk yang akan dihasilkan. Sistem pemeliharaan semi intensif yaitu itik dikandangkan pada waktu tertentu biasanya pada sore hari sampai pagi kemudian digembalakan untuk memenuhi kebutuhannya tanpa diatur oleh peternak. Sistem pemeliharaan intensif yaitu itik yang sistem pemeliharaannya di dalam kandang dengan berbagai aktivitasnya semua kebutuhan dipenuhi oleh peternak (Gumelar dan Rahmat, 2008) (Wulandari, Sunarti, \& Kismiati, 2019).

Pergeseran pola/sistem budidaya itik ini disebabkan oleh berkurangnya tempat penggembalaan antara lain karena makin intensifnya penanaman padi di sawah, konversi atau alih fungsi lahan persawahan menjadi daerah pemukiman dan industri. Selain itu juga karena meningkatnya kesadaran peternak dalam mencegah dan menularnya penyakit unggas seperti Avian Influenza (Peraturan Mentri Pertanian Nomor: 35/Permentan/OT. 140/3/2007, 2007).

Masyarakat desa selalu memiliki ciri-ciri atau dalam hidup bermasyarakat, biasanya tanpak dalam perilaku keseharian mereka. Pada situasi dan kondisi tertentu, sebagian karakteristik dapat digeneralisasikan pada kehidupan masyarakat desa di daerah tertentu (Koentjaraningrat, 2002). Menurut Sandi et al. (2016), secara nasional populasi ternak itik terus meningkat dari tahun ke tahun. Pada tahun 2018, diketahui itik yang tersebar di seluruh provinsi di Indonesia telah mencapai lebih dari 47 juta ekor (Turangan, Manese, \& Pangemanan, 2020).

Bayang merupakan salah satu kecamatan yang terletak di Kabupaten Pesisir Selatan, Provinsi Sumatera Barat, Indonesia. Kecamatan ini terletak sekitar 75 km dari kota Padang arah ke selatan, yaitu sesudah kecamatan Koto XI Tarusan dari arah kota Padang menuju kota Painan (Kecamatan Bayang, 2005). Peternak itik di Kecamatan Bayang, Kabupaten Pesisir Selatan lebih memilih pemeliharaan ternak itik dengan digembalakan secara berpindah-pindah dari satu lahan sawah ke lahan sawah yang lainnya, apalagi peternak menilai usaha yang seperti ini lebih menguntungkan, dibandingkan pemeliharaan dengan cara di kandangkan. Berdasarkan data yang didapatkan di Kecamatan Bayang bahwa luas daerah menurut nagari bayang berjumlah 77,50. 
Kartika Afrinalsari, Nora Susilawati Resolusi Konflik Peternak Itik dengan Pemilik Sawah dan Masyarakat Kecamatan Bayang Kabupaten Pesisir Selatan

Tabel 1. Persentase Luas Lahan Menurut Jenis Penggunaannya 2017

\begin{tabular}{clc}
\hline No. & \multicolumn{1}{c}{ Penggunaan } & Luas $(\mathbf{H a})$ \\
\hline 1. & Lahan Sawah & $2.246,00$ \\
\hline 2. & Bagunan dan halaman sekitarnya & 716 \\
\hline 3. & Tegal, Kebun & 532 \\
\hline 4. & Ladang, Huma & 0 \\
\hline 5. & Penggembalaan, Padang Rumput & 48 \\
\hline 6. & Sementara tidak diusahakan & 150 \\
\hline 7. & Ditanami pohon atau hutan rakyat & 442 \\
\hline 8. & Hutan Negara & 609 \\
\hline 9. & Perkebunan & 2427 \\
\hline 10. & Tebat, Kolam, Empang & 577
\end{tabular}

Sumber : Dinas Tanaman Pangan, Hortikultura dan Perkebunan Kabupaten, 2017

Berdasarkan data yang didapatkan di Kecamatan Bayang bahwa persentase luas lahan menurut jenis penggunaannya yaitu luas lahan sawah 2.246; luas bangunan dan halaman sekitarnya 71; luas tegal \& kebun 532; luas ladang dan huma 0 ; luas penggembalaan, padang rumput 48; luas sementara tidak di usahakan 150; luas yang ditanami pohon atau hutan rakyat 442; luas hutan Negara 609; luas perkebunan 2427; luas tebat/ kolam/ empang 577.

Sebelum program intensifikasi pertanian menjadi program nasional, pemeliharaan itik secara tradisional atau dengan digembala memang sangat menunjang konsep pengendalian hama pertanian secara terpadu. Itik umumnya mencari makan di permukaan sawah dan sekitar batang/rumpun pada batang padi. Namun sejak penggunaan obat-obatan pembasmi hama pertanian makin intensif dan adakalanya dosisnya berlebihan, kasus keracunan itik sering menimbulkan konflik sosial.

Konflik menurut Lawis A. Cosser adalah perselisihan nilai-nilai atau tuntutan-tuntutan yang berkenaan dengan status kuasa dan sumber-sumber kekayaan yang tidak mencukupi, di mana pihak-pihak tidak hanya bermaksud memperoleh barang yang diinginkannya, melainkan juga ingin memojokkan lawannya. Coser juga menyebutkan konflik dapat berlangsung antara individu dengan individu, individu dengan kelompok, maupun kelompok dengan kelompok. Coser juga menyebutkan bahwa konflik tidak selamanya bersifat negatif, tetapi juga mempunyai sifat yang positif, dalam hal membantu mewujudkan rasa persatuan dan kesadaran akan hidup bermasyarakat. Hal ini tergantung dari cara dan kelanjutan dari konflik itu sendiri. Konflik dengan kelompok lain dapat memerlukan identitas kelompok dan melindunginya agar tidak kabur ke dalam dunia sosial sekelilingnya (Poloma, 2004). Lewis Coser menegaskan, konflik selain berfungsi sebagai sistem penyeimbang, juga berfungsi positif terhadap masyarakat melalui perubahan-perubahan sosial yang ditimbulkannya (Setiyani, 2016). Perubahan sosial memang akan muncul dengan sendirinya seiring dengan petumbuhan masyarakatnya. Akan tetapi diperlukan campur tangan manusia untuk menentukan arah perubahan, karena manusia memiliki kemampuan untuk menanggapi perubahan, baik sebagai perancang strategi perubahan maupun sebagai agen perubahan itu sendiri. (Lauer, 1993) (Syafrini, Susilawati, \& Hasmira, 2016)

Resolusi konflik yang dalam bahasa Inggris adalah conflict resolution memiliki makna yang berbeda-beda menurut para ahli yang fokus meneliti tentang konflik. Resolusi dalam Webster Dictionary menurut Levine (1998: 3) adalah (1) tindakan mengurai suatu 
permasalahan, (2) pemecahan, (3) penghapusan atau penghilangan permasalahan (Yumnah, 2010).

Dulunya hubungan antara pemilik sawah (saudara, tetangga, orang lain) dengan pemilik ternak saling menguntungkan satu sama lain. Yang mana terlihat hubungan yang saling menguntungkan pada pemilik sawah yang sudah panen dapat mengurangi penggunaan pastisida dan pupuk kimiawi sehingga biaya produksi petani juga berkurang. Dan pemilik ternak dapat menggunakan lahan pertanian yang sudah di panen tersebut untuk pengembangbiakkan itik-itiknya.

Namun, saat ini hubungan antar peternak itik dengan pemilik sawah sudah mulai renggang. Saat ini terdapat pandangan buruk pemilik sawah dengan peternak itik. Yang mana pemilik sawah tidak ingin sawahnya dimasuki oleh itik karena takut sawanya akan hancur atau berantakkan. Sikap dari pemilik sawah yang tidak ingin sawahnya di kotori oleh itik menimbulkan konflik antar pemilik sawah (saudara, tetangga, dan orang lain) dengan peternak itik tersebut. Akibatnya para peternak itik harus mencari sawah yang sudah di panen dan sawah yang pemiliknya mau menerima atau menompangkan itik si peternak di sawahnya selama sawahnya belum di tanami kembali. Tempat pemeliharaan atau pengembalaan itik biasanya di lahan sendiri, lahan sawah milik saudara, tetangga dan orang lain yang sawahnya sudah panen.

Penelitian yang relevan mengenai Peternak Itik juga telah dilakukan oleh Suzeth G. Tinenta, S. O. B. Lombogia, F. S. Oley, J. M, dengan judul "Peranan Kelompok Peternak Terhadap Usaha Pengembangan Ternak Itik Di Kecamatan Tondano Barat, Kabupaten Minahasa." Pembanguna peternakan secara umum, dimaksudkan untuk meningkatkan taraf hidup masyarakat pedesaan terutama peternak, dengan cara meningkatkan produksi peternakannya. Disamping itu, dilakukan usaha untuk memenuhi kebutuhan akan gizi masyarakat yang ada di pedesaan. Selanjutnya, untuk mengubah cara pemeliharaan dari tradisional kearah pemeliharaan intensif, diperlukan suatu pemahaman dan pengetahuan beternak itik yang lebih baik. Hal ini bersamaan berperan menciptakan lapangan pekerjaan di masyarakat pedesaan (Subagja, Erlina, \& Kustiawan, 2017).

Penelitian mengenai Peternak Itik juga dilakukan oleh Setioko A. R, S. Iskandar, dkk, dengan judul "Model Usaha Ternak Itik Dalam Sistem Pertanian Dengan Indek Pertanaman Padi Tiga Kali Per Tahun IP" Pemeliharaan itik di sawah mempunyai pengaruh baik pada peternaknya maupun pada petani pcmilik sawah. Pengaruh timbal balik ini menunjukkan kepentingan masing-masing. Hasil survai menunjukkan balnva keuntungan bagi petani padi di Pemalang antara lain bahwa keberadaan itik di sawah mereka justru dapat mcmangsa hama penyakit padi dan juga dapat menyuburkan sawah karena mengeluarkan kotoran selama digembala. Di Subang, petani padi merasa untung karena itik memangsa hama penyakit padi. Kerugian itik gembala bagi petani selain dapat merusak sawah yang masih hijau, juga dapat masuk ke areal sawah yang belum dipanen dan memangsa padi yang belum dipanen (R, Iskandar, Raharjo, Soedjana, \& Murtisari, 2000).

\section{Metode Penelitian}

Penelitian ini dilakukan di Kecamatan Bayang, Kabupaten Pesisir Selatan, Provinsi Sumatera Barat. Dipilih karena sebagian besar masyarakat di Kecamatan Bayang memiliki mata pencaharian sebagai peternak itik.

Penelitian menggunakan pendekatan penelitian kualitatif dengan tipe studi kasus (Basrowi \& Suwandi, 2008). Bog dan Taylor mendefinisikan metodologi kualitatif sebagai prosedur penelitian yang menghasilkan data deskriptif berupa kata-kata tertulis atau lisan dari 
orang-orang dan perilaku yang dapat diamati. Tipe penelitian yang digunakan adalah studi kasus karena penelitian ingin memperoleh informasi lebih jelas mengenai sebuah kasus yaitu resolusi konflik peternak itik dengan pemilik sawah dan masyarakat Kecamatan Bayang Kabupaten Pesisir Selatan. Pada penelitian ini peneliti dalam memilih informan yaitu dengan cara purposive sampling dengan jumlah 14 orang. Teknik untuk mengumpulkan data yang digunakan dalam penelitian ini yaitu (1) Observasi; (2) Wawancara; dan (3) Studi Dokumentasi (Burhan, 2005). Analisis data yang digunakan dalam penelitian ini yaitu dengan mengadopsi yang dikembangkan oleh Milles dan Hurberman melalui analisis yang terdiri dari tiga alur kegiatan, (1) reduksi, (2) penyajian data, dan (3) kesimpulan/verivikasi.

\section{Hasil dan Pembahasan}

Berdasarkan hasil wawancara yang diperoleh dengan mewawancarai 14 orang informan yang terdiri dari 5 orang peternak itik, 4 orang pemilik sawah, 3 orang masyarakat, 1 orang datuak, dan 1 orang wali nagari terkait dengan permasalahan proses dan hasil resolusi konflik peternak itik dengan pemilik sawah dan masyarakat Kecamatan Bayang Kabupaten Pesisir Selatan.

Wehr dalam bukunya conflic resolution, mengemukakan konflik dan pertikaian adalah hal yang tidak dapat terhindarkan di dalam kelompok sosial. Menurutnya konflik merupakan suatu konsekuensi dari komunikasi yang buruk, salah pengertian, salah perhitungan dan proses lain yang tidak disadari. Wehr juga menyimpulkan bahwa selain merupakan hal yang alamiah konflik juga memiliki dinamika tertentu yang baru diramalkan kehadirannya dan dapat diarahkan secara konstruktif dan dia juga berpendapat bahwa di dalam konteks keluarga, kelompok, atau masyarakat juga berkaitan langsung dengan struktur pengatur kekuasaan (Chandra, 1992). Prof. Dr. Alo Liliweri berpendapat bahwa resolusi konflik bertujuan menangani sebab-sebab konflik dan berusaha membangun hubungan baru yang relatif dapat bertahan lama diantara kelompok-kelompok yang bermusuhan (Hasyah, 2018).

Resolusi konflik difokuskan pada sumber konflik antara dua pihak, agar mereka bersamasama mengidentifikasi isu-isu yang lebih nyata. Kalau kedua pihak tidak setuju atas isu yang sudah digariskan, maka kita membutuhkan negosiator. Seorang negosiator (fasilitator) itu penting ketika konflik makin luas dan tidak dapat ditekan, karena sudah mengandung emosi dan ancaman.

Konflik yang terjadi antara peternak itik dengan pemilik sawah dan masyarakat di sekitar Kecamatan Bayang, Kabupaten Pesisir Selatan di sebabkan oleh masuknya itik ke dalam sawah yang sedang ditanami baniah padi dan itik tersebut memakan baniah padi sehingga membuat petani sawah marah dan melempari itik tersebut dengan batu atau pun kayu yang ada disekitaran sawah. Tidak hanya pemilik sawah yang merasa terganggu adanya itik di daerahnya, namun masyarakat juga merasa terganggu. Saat itik ingin digembalakan ke sawah yang sudah panen itik tersebut harus di tuntun ke arah sawah tempat pengembalaan itik melalui jalan raya. Keberadaan itik di jalan raya menyebabkan jalan menjadi macet, pengendara mobil, motor dan becak saling mengelakson dan menimbulkan keributan di jalan. Saat dikelakson itikitik pun mulai menyebar mendengar kelakson tersebut sehingga masuk ke rumah-rumah warga yang dekat dengan jalan raya. Tidak hanya itu saja warga yang rumahnya dimasuki oleh itik pun menghalau itik-itik tersebut dengan sapu, serta pengendara mobil, motor dan becak yang tidak sabaran akhirnya menabrak salah satu itik tersebut sehingga itik tersebut ada yang pincang, serta ada juga yang mati, tidak hanya itu saja pengendara motor juga berkata-kata kasar kepada peternak itik sehingga peternak itik terpancing emosi dan membalas perkataan 
kasar pengendara motor tersebut sehingga menimbulkan percekcokan antar mulut. Akibat hal tersebut dicarilah jalan keluarnya. Proses pencapaian keluaran konflik melalui beberapa tahap yaitu:

\section{Negosiasi Antara Peternak dengan Pemilik Sawah dan Masyarakat}

Setelah diketahui penyebab terjadinya konflik peternak dengan pemilik sawah dan masyarakat. Maka diadakanlah negosiasi untuk mencari jalan keluaran konflik tersebut sebagaimana sebaiknya dan langkah apa yang harus mereka ambil.

\section{Mediasi dengan Datuak}

Dalam buku Konflik dan Manajemen konflik mendefenisikan resolusi konflik melalui mediasi sebagai proses manajemen konflik dimana pihak-pihak yang terlibat konflik menyelesaikan konflik mereka melalui negosiasi untuk mencapai kesepakatan bersama (Wirawan, 2010). Mediasi merupakan suatu proses yang memerlukan upaya dari pihak yang terlibat konflik dan mediator. Dikatakan proses karena mediasi juga memerlukan sumbersumber berupa keinginan pihak yang terlibat konflik untuk menyelesaikan konflik dengan bantuan mediator setelah tidak mampu menyelesaikan sendiri konflik mereka. Sama halnya dengan konflik peternak itik dengan pemilik sawah, mereka tidak mampu menyelesaikan sendiri konflik mereka, maka dari itu mereka menggunakan mediasi oleh Datuak yang membantu menyelesaikan konflik mereka.

\section{Albitrasi dengan Wali Nagari}

Setelah kedua belah pihak mengadakan pertemuan dan mendapatkan hasil keputusan yang akan mereka tuntut, setelah itu ke dua belah pihak yang berkonflik mengadakan pertemuan dengan Wali Nagari. Disitu mereka mengadakan pertemuan dengan Wali Nagari supaya konflik ini diketahui oleh Wali Nagari dan apabila konflik ini terjadi lagi maka peternak itik dan pemilik sawah dapat dituntut dan dibawa ke jalur hukum.

Resolusi konflik antara peternak itik dengan pemilik sawah sampai saat ini masih diselesaikan secara informal karena mereka memilih menyelesaikan secara kekeluargaan, namun disini mereka meminta bantuan Wali Nagari yang bersifat formal untuk menengahi konflik yang terjadi karena peternak dan pemilik sawah menginginkan adanya lembaga formal yang menengahi konflik ini, jika keputusan bersama yang telah disepakati dilanggar maka peternak ataupun pemilik sawah akan dikenakan hukuman sesuai dengan peraturan perundangundangan yang berlaku.

Setelah proses pencapaian keluaran konflik melalui beberapa tahap tersebut telah dilakukan maka hasil keputusan musyawarah yang terjadi antara peternak itik dengan pemilik sawah dan masyarakat sekitar yang dibantu oleh datuak dan wali nagari sebagai mediator, yaitu:

\section{Keputusan secara musyawarah}

Melalui musyawarah antara peternak itik dengan pemilik sawah serta masyarakat maka hasil keputusan yang diambil dalam menyelesaikan konflik tersebut ialah secara kekeluargaan. Konflik tersebut diselesaikan secara baik-baik dan di saksikan oleh datuak dan wali nagari sebagai mediatornya. Mereka tidak memperpanjang masalah tersebut dan mereka mencari jalan keluar agar itik milik peternak tidak masuk ke sawah yang tidak mendapatkan izin dari pemiliknya dan masuk ke sawah yang sedang di tanami baniah padi.

Solusi yang diambil yaitu dengan cara memasang jaring-jaring di pinggiran sawah tempat itik mencari makan, agar itik tersebut tidak masuk kesawah yang lain dan peternak itik juga harus meminta izin terlebih dahulu untuk mengembalakan itik di sawah orang lain, peternak 
itik juga harus mengawasi itik-itiknya agar tidak masuk ke rumah-rumah warga dan tidak meletakkan itik-itiknya di samping rumah warga agar warga tersebut tidak merasa terganggu dengan suara-suara itik tersebut. Dengan solusi tersebut konflik yang terjadi antara peternak itik dengan pemilik sawah dan masyarakat sekitar dapat berkurang.

\section{Tuntutan ganti rugi}

Setelah tercapainya hasil keputusan secara musyawarah yang diambil oleh kedua belah pihak yang berkonflik, maka keputusan tidak berakhir begitu saja, mereka saling menuntut ganti rugi, peternak itik meminta ganti rugi itik-itiknya yang mati kepada pemilik sawah dan pemilik sawah juga meminta ganti rugi untuk baniah padinya yang telah rusak akibat itik-itik peternak. Namun, setelah diadakan negosiasi maka peternak dan pemilik sawah memutuskan untuk meminta ganti rugi sebesar Rp 100.000 untuk ganti rugi itik-itik peternak dan ganti rugi sebesar Rp 150.000 untuk ganti rugi baniah yang rusak tersebut.

Dalam resolusi konflik, terdapat adanya negosiasi pada proses penyelesaian konflik, dimana interaksi konflik dengan tujuan menciptakan kolaborasi atau kompromi (win \& win solution) proses resolusi konflik dicapai melalui interaksi konflik salah satunya yaitu menyatakan bertanggung jawab atas sesuatu kejadian atau kerugian lawan konflik.

\section{Kesimpulan}

Konflik merupakan fenomena sosial yang dapat terjadi dalam kehidupan sehari-hari manusia. Hal itu bisa terjadi di manapun dan melanda komunitas manapun. Konflik bisa terjadi pada masyarakat yang homogen maupun masyarakat yang heterogen. Berdasarkan konflik yang terjadi antara Peternak Itik dan Pemilik Sawah serta Masyarakat sekitar Kecamatan Bayang Kabupaten Pesisir Selatan, karena peternak tidak meminta izin untuk mengembalakan itiknya di sawah dan itik peternak telah memakan baniah padi, serta pemilik sawah telah membunuh dan menganiaya itik milik peternak dan suara itik yang mengganggu kenyamanan masyarakat akibat tempat penangkaran itik yang dekat dengan rumah warga. Dari hasil penelitian tentang konflik peternak itik dengan pemilik sawah dan masyarakat dapat disimpulkan bahwa proses dan hasil resolusi konflik melalui tiga tahap yaitu: (1) Negosiasi antara peternak itik dengan pemilik sawah dan masyarakat, (2) Mediasi dengan Datuak, (3) Arbitrasi dengan Wali Nagari. Hasil resolusi konflik yang telah disepakati yaitu: (1) Keputusan secara musyawarah, (2) Tuntutan ganti rugi sebesar Rp 100.000 untuk ganti rugi itik-itik peternak dan ganti rugi sebesar Rp 150.000 untuk ganti rugi baniah yang rusak.

\section{Daftar Pustaka}

Basrowi, \& Suwandi. (2008). Memahami Penelitian Kualitatif. Jakarta: Rineka Cipta.

Burhan, B. (2005). Metodologi Penelitian Kuantitatif: Komunikasi, Ekonomi, dan KebijakanPpublik serta Ilmu-Ilmu Sosial Lainnya. Jakarta: Pranada Media.

Chandra, R. I. (1992). Konflik Dalam Kehidupan Sehari-hari. Bandung: Kanisius.

Hasyah, D. Al. (2018). Konflik dan Resolusi Konflik dalam Pengembangan Masyarakat: Studi Kasus Konflik Sangketa Lahan Antara Warga Sosrokusuman Dengan PT. Bangun Jogja Indah. International Journal of Machine Tools and Manufacture, 5(1), 86-96. https://doi.org/10.1016/j.ijmachtools.2009.09.004

Helmi, R. (2013). Analisis Pendapatan Peternakan itik Pedaging di Desa Mattongan-Tongang Kecamatan Mattiro Sompe Kabupaten Pinrang. Skripsi. Universitas Hasanuddin

Insani, A., Budji, R. G., Djide, M. N., \& Hassan, M. S. (2013). Pengaruh Pemberian Tipe 
Kartika Afrinalsari, Nora Susilawati

Probiotik pada Pakan Itik Pedaging Anas Domesticus Untuk Menurunkan Kadar Kolesterol. Skripsi. Universitas Hasanuddin.

Kecamatan Bayang. (2005). Profil Kecamatan Bayang dan Wilayah Administrasi. Pesisir

Selatan: Kecamatan Bayang.

Koentjaraningrat. (2002). Pengantar Ilmu Antropologi. Jakarta: Rineka Cipta.

Lutfi, U. M., Hendriani, R., Suyono, A., Malvin, T., \& Mukhlis. (2018). Analisis Kelayakan Usaha Pola Pemeliharaan Semi Intensif Kering Itik Petelur Dara (Fase Grower) Umur Dua Bulan di Kabupaten Limapuluh Kota. Seminar Nasional Pusat P2M Politanikoe. Kupang

Peraturan Mentri Pertanian Nomor: 35/Permentan/OT. 140/3/2007.

Poloma, M. M. (2004). Sosiologi Kontemporer. Jakarta: Rajagrafindo Persada.

R, S. A., Iskandar, S., Raharjo, Y. C., Soedjana, T. D., \& Murtisari, T. (2000). Model Usaha Ternak Itik dalam Sistem Pertanian dengan Indek Pertanaman Padi Tiga Kali Per Tahun IP. 5.JITV, 5(1), 276-278

Rahman, M., Sirajuddin, S. N., \& Asnawi, A. (2019). Biaya Transaksi Pada Pemeliharaan Ternak Itik Berpindah di Kabupaten Pinrang. Jurnal Agrisistem, 15(1), 9-14.

Setiyani, W. (2016). Tipologi dan Tata Kelola Resolusi Konflik Ditinjau dari Perspektif Teori Sosial Konflik. Teosofi: Jurnal Tasawuf dan Pemikiran Islamemikiran Islam, 6(2), 275299.

Subagja, H., Erlina, N. P., \& Kustiawan, E. (2017). Analisis Kelayakan Peternakan Tradisional Itik Petelur Kabupaten Jember. Jurnal Ilmu Peternakan Terapan, 1(1), 39-44.

Syafrini, D., Susilawati, N., \& Hasmira, M. H. (2016). Partisipasi Masyarakat Lokal dalam Mengembangkan Kawasan Wisata Keluarga. Jurnal Socius: Journal of Sociology Research and Education, 3(2), 122-139.

Turangan, L. Y., Manese, M. A. V., \& Pangemanan, S. P. (2020). Kontribusi Usaha Ternak Itik Petelur Terhadap Pendapatan Rumah Tangga Petani Peternak di Kecamatan Longowan Timur. Zootec, 40(1), 81-93.

Wardhani, P. A. (2015). Efikasi Diri dan Pemahaman Konsep IPA dengan Hasil Belajar Ilmu Pengetahuan Alam Siswa Sekolah Dasar Negeri Kota Bengkulu. Jurnal Pendidikan Dasar UNJ, 6(1), 58-67. https://doi.org/10.1017/CBO9781107415324.004

Wulandari, M., Sunarti, D., \& Kismiati, S. (2019). Kualitas Interior Telur Itik Tegal dengan Sistem Pemeliharaan Semi Intensif dan Intensif di KTT Bulusari Kabupaten Pemalang. Jurnal Peternakan Indonesia, 21(2), 85-92. https://doi.org/10.25077/jpi.21.2.8592.2019

Yumnah, S. (2010). Menggunakan Nilai-Nilai Agama dan Pancasila Piil Pesenggiri : Strategi Resolusi Konflik Piil Pesenggiri: Strategy of Conflict Resolution That. Jurnal Cakrawala Pendidikan, 1(1), 237-252. https://doi.org/10.21831/cp.v1i1.214 